RASĀYAN J. Chem.

Vol. 13 | No. 4 |2544-2551| October - December | 2020 ISSN: 0974-1496 | e-ISSN: 0976-0083 | CODEN: RJCABP

RJC http://www.rasayanjournal.com http://www.rasayanjournal.co.in

\title{
SYNTHESIS AND ANTI-BREAST CANCER ACTIVITIES OF ALPHA MANGOSTIN DERIVATIVES: A REVIEW
}

\author{
Muhammad Fauzi and Muchtaridi Muchtaridi* \\ Department of Pharmaceutical Analysis and Medicinal Chemistry, Faculty of Pharmacy, \\ Universitas Padjajaran, 45363 Sumedang, Indonesia. Telephone / Fax: (022) 7796200 \\ *E-mail: muchtaridi@unpad.ac.id
}

\begin{abstract}
Alpha mangostin is the main part of xanton in mangosteen pericarp and is the main candidates for use in breast cancer drugs. Several studies were carried out in vitro, in vivo, and in silico study which showed that alpha mangostin and its derivatives have activity as a cure for breast cancer. This review article provides information alpha mangostin and its derivatives regarding their activities as anti-breast cancer which focuses on synthesis work, molecular targets, modes of action, and structure-activity relations (SAR). The development of beneficial alpha mangostin as complementary or alternative medicine can provide new opportunities for drug discovery against the disease.
\end{abstract}

Keywords: Alpha Mangostin, Synthesis, Anti-breast Cancer, Drugs Development.

(C) RASĀYAN. All rights reserved

\section{INTRODUCTION}

Cancer is a multifactorial disease with a long process by promotion and development. During the carcinogenic process, there will be stages that show a progressive change from a normal cell to become cancer cells. These cellular changes result in inhibition of growth and apoptosis, insensitivity to receiving growth signals, potential uncontrolled replication and continuous angiogenesis, tissue invasion, and metastasis of all parts of the body. ${ }^{1}$

Breast cancer is one of the most common types of cancer in women in 2020, with more than 200 thousand people diagnosed or as much as $29 \% .{ }^{2}$ Data on cancer enrolled from hospitals indicated breast cancer as malignant cancer that is commonly found in Indonesia, surpassing cervical cancer. To date, more than 10.000 patients with breast lumps have been diagnosed with breast cancer. There were 178.480 predicted new breast cancer patients, and 40.460 people died in the USA from 2007 to 2017. In 2018 there has been an increase in the number of breast cancer cases which are in third place with around 18 million cases and in the top five with the most total deadths. ${ }^{3}$

Chemotherapy is still the primary choice in cancer therapy over the last decade. Nonetheless, the success rate of chemotherapy was still low due to their adverse side effects and resistance. This resistance is due to the nature of work when the drug is neither selective nor specific as an anticancer. Therefore, the development of a new anticancer focused on efforts to get the work selectively and specifically, directed against genomic and molecular abnormalities. ${ }^{4}$

The drugs discovery and development is a long and difficult process. The first study which is generally a time to discover, develop, and recognize a new drug in the US has increased sharply from 8.1 years in 1960 to 14.2 years in 1990 . The actual time takes much longer ranging from chemical synthesis, time to drug target identification and selection process that generally takes two years or more. ${ }^{5}$

Drug discovery and development continues to attract great attention through the synthesis of chemicals that form compounds to target enzymes in the treatment of various cancers. ${ }^{6}$ This drug development is an effort that can be done to encourage the availability of drugs in Indonesia in increasing food and drug security. ${ }^{7}$ Therefore, it is expected that the chemical synthesis of new compounds will enhance the self-sufficiency in the production of medicines, especially for anticancer drugs. Thus, the synthesis of new compounds such as xanthone derivative could be a great work of Indonesia in strengthening food security and medicine. 
RASĀYAN J. Chem.

Vol. 13 | No. 4 |2544-2551| October - December | 2020

Cancer drug discovery and development is pursued to obtain drugs with a specific work mechanism and safe for people with cancer, especially breast cancer. There is an alternative way i.e. medicinal plants to be developed as herbal remedies for cancer. Mangosteen (Garcinia mangostana L) is a plant that grows in Southeast Asia and is widespread in several countries. the mangosteen fruit production is increasing every year with a total production of 113.096 tons in 2014. The production process is found in the area of Tasikmalaya, Bogor, Sukabumi, South Tapanuli, Tabanan, and West Lombok. Mangosteen pericarp is widely used as an alternative treatment for various diseases because xanthone containing compounds and derivatives include alpha, beta-,and gammamangostin, garsinon, 8-deoksigartanin, gartanin, and mangostanol

Mangosteen pericarp is used as a raw material for medicinal agents for breast cancer therapy. Evaluation of mangosteen pericarp still needs to be done because it has not been used optimally and is still considered a difficult waste to rot if left in the air for more than 30 days and will not experience degradation so that it can pollute the environment. This is because the mangosteen pericarp is antioxidant and antibacterial ${ }^{10}$. Alpha mangostin is the most important secondary metabolite found in mangosteen pericarp in oxygenated xanton and xanton prenylation. Some structural derivatives of alpha mangostin compounds have biological activities such as anti-inflammatory, ${ }^{11-13}$ antioxidants, ${ }^{14-16}$ antiallergy, ${ }^{17-19}$ antibacterial, ${ }^{20-22}$ antifungal, ${ }^{23-25}$ antiparasitic, ${ }^{26,27}$ antitumor gene, ${ }^{28-30}$ antimalarial, ${ }^{31-33}$ anticancer, ${ }^{34-38}$ antiproliferation, ${ }^{39-41}$ and immune system defense, ${ }^{42}$ based on the type of structure.

Alpha mangostin as the main xanthone derivative from the mangosteen is reported to be a potential compound candidate in the treatment of breast cancer. Alpha mangostin anticancer has a mechanism such as antiproliferative associated with suppression of tumor growth and metastasis in vivo in mouse models of breast cancer. Based on theMCF-7 breast cancer cell model, the alpha mangostin can inhibit the growth process by decreasing the function of $\mathrm{hER} \alpha,{ }^{43}$ Mangosteen peel extract shows activity as an antiproliferating agent and apoptosis inducer on breast adenocarcinoma cell line MCF-7 with IC50 value of 45 $\mu \mathrm{g} / \mathrm{mL}$, while alpha mangostin had $\mathrm{IC}_{50}$ value of $20 \mu \mathrm{g} / \mathrm{mL}$. The IC50 value including cytotoxic active moderate category $(10-100 \mu \mathrm{g} / \mathrm{mL}) .{ }^{41}$ Therefore, synthesis and characterization methods can increase the activity and affinity of compounds as antagonists of the alpha estrogen receptors.

The active compounds of a plant can be used as therapeutic agents, but most secondary metabolites do not show optimal activity. In this case, it is due to a lack of specificity and the absence of biologically active functional groups. Thus, by describing the structure of active compounds and pharmacophores, functional groups are considered important to increase the activity of a metabolite compound. To enhance the bioavailability of alpha mangostin, semi-synthetic modifications of these compounds lead to more active compounds, without excessive toxicity. ${ }^{44}$

Women who suffer from obesity in the postmenopausal phase are at increased risk of developing breast cancer. Differences in lifestyle and eating habits also play e a role in the development of cancer. Women are more at risk of developing breast cancer than men because women have more estrogen and progesterone which can encourage the growth of breast cancer cells. ${ }^{45}$ Breast cancer has morphological and molecular characteristics that are very complex. One important marker for the prognosis of breast cancer is estrogen receptor. ${ }^{46}$ Approximately $60 \%$ of breast cancer is indicated by estrogen receptor- $\alpha$ (ER- $\alpha$ ) expression. ${ }^{47}$ The development of a new drug molecule term has developed rapidly to support cancer therapy. The receptor estrogen alpha is a molecular target in the inhibition of breast cancer. ${ }^{48}$

\footnotetext{
Alpha Mangostin

Alpha mangostin is xanthone derived compounds that have a molecular formula $\mathrm{C}_{23} \mathrm{H}_{26} \mathrm{O}_{6}$ with a molecular weight of 410.45964. Alpha mangostin has the IUPAC name of 1,3,6-Trihydroxy-7-methoxy-2,8-bis (3methylbut-2-en-1-yl)-9H-xanthene-9-one. ${ }^{49}$ Alpha mangostin has various bioactivity and is used as a marker compound in mangostin pericarp, it is the most abundant component. ${ }^{50}$ Other studies reported that alpha mangostin also has anti-inflammatory activity as well as anti-cancer activity. ${ }^{51}$ The structure of alpha mangostin is illustrated in Fig.-1.
}

Anti-breast Cancer Activity

A study by kritsanawong of alpha mangostin was reported through induction of apoptosis and T47D breast cancer signaling pathways. Human epidermal growth factor receptor 2 (HER2) and mitogen-activated 
RASĀYAN J. Chem.

Vol. 13 | No. 4 |2544-2551| October - December | 2020

protein kinase (MAPK) has been shown to have an important role in the process of apoptosis. The results showed that the alpha mangostin induces cell proliferation process of DNA fragmentation, nuclear condensation, increased caspase- 3 and caspase- 9 split truncated but decreased the expression of Bcl-2 and Mcl-1. Mitochondria dysfunction and the release of cytochrome are also detected. Also, phosphorylation of ER $\alpha, H E R 2, \mathrm{PI} 3 \mathrm{~K}$, Akt and ERK1/2-derived regulation occurred while p-JNK1 /2 and p-p38 upregulated..$^{52}$<smiles>COc1c(O)cc2oc3cc(O)c(CC=C(C)C)c(O)c3c(=O)c2c1CC=C(C)C</smiles>

Fig.-1: Alpha Mangostin (1) Structure

Alpha mangostin antimetastatic was effective as an agent to inhibit MMP-2 and MMP-9 expression in MCF-7. Alpha mangostin can inhibit TPA induction of adhesion, invasion, and migration and cell-matrix adhesion test and test Boyden chamber. Alpha mangostin can inhibit kinase activation of extracellular signal-regulated 1 and 2 (ERK1/2) which is involved in the downregulation of the enzyme activity, protein, and messenger RNA levels of MMP-2 and MMP-9 induced by TPA. Specific inhibitor treatment on ERK (U0126) for MCF-7 cells can inhibit MMP-2 which is induced by TPA and expression of MMP-9 is inhibited during the cell migration. Based on these results alpha-mangostin is an effective new agent, effective, antimetastatic-functioning genes downregulated MMP-2 and MMP-9. ${ }^{53}$

The estrogen receptor is one of the main prognostic factors and predictive factors examined in breast cancer. The estrogen receptor consists of ER $\alpha$ and ER $\beta$ which have a different affinity to estrogen. A study by Muchtaridi reported that alpha mangostin is a potential candidate for breast cancer drugs through computational simulation using the in silico method.On the other hand, HER $\alpha$ protein is also targeted in cancer drug discovery using alpha mangostin, based on the interaction of hydrogen bond with amino acid residues such as glutamine 419 with histidine 54 , and glutamine 419 with lysine 531 . The hydrogen bonding can be represented by the potential ligand fluctuation for the HER $\alpha$ receptor antagonist. The Alpha mangostin and AMD10 ligand have hydrogen bonds with fluctuations interfered by amino acid residues of serine 432 , and serine521 so that alpha mangostin it can be explained that alpha mangostin and AMD10 have inhibitory activity against HER $\alpha$. The AMD10 modified is the best of all alpha mangostin analog and identified using computer-assisted molecular simulation. Alpha mangostin, AMD10, and other analogs met all the bioavailability parameters according to the Lipinski Rule Five. The result of molecular docking obtained free energy alpha mangostin of $-9.05 \mathrm{kcal} / \mathrm{mol}$ and AMD10 of $-11.89 \mathrm{kcal} / \mathrm{mol}$ and based on the prediction result of pharmacophores also meet the requirements. ${ }^{54}$

\section{Synthetic Modifications}

Alpha mangostin has been targeted in various synthesis pathway through several chemical reactions. The basic structure of xanthone is maintained and the functional groups such as iso-prenyl, phenolic hydroxy, and ketones being modified in the drug design and synthesis.

A study of the development of early analog by Ren et al ${ }^{55}$ has reported that3, 6-deacetylation (34) or 6benzoylation (35) compounds have a cytotoxic enhancement of alpha mangostin (1). The addition of cyclic groups to at the $\mathrm{C}-2$ and $\mathrm{C}-3(33,36)$ maintains the previous cytotoxic potential whereas the addition of cyclic groups to the $\mathrm{C}-1$ and $\mathrm{C}-2$ chains (37) greatly reduces the activity of these compounds. Consistently, other studies have shown that a derivative of alpha mangostin di-O-alkylated reduces cytotoxicity, compared with $1 .{ }^{56}$ Based on the research, Fei et $\mathrm{al}^{57}$ have synthesized new analog alpha mangostin through sub-substitution of the hydroxyl group at the $\mathrm{C} 1, \mathrm{C} 3$ and $\mathrm{C} 6$ (34 and 38-49), cyclization at the $\mathrm{C}-2$ and $\mathrm{C}$ 3 (50), modification The C-4 (51-53) and C-7 (54 and 55). Cytotoxicity activity screening studies were identified with a potential cytotoxic agent such as $\mathbf{4 0}, \mathbf{4 6}, \mathbf{5 1}$ and $\mathbf{5 2}$, but all of them showed reduced activity, 
RASĀYAN J. Chem.

Vol. 13 | No. 4 |2544-2551| October - December | 2020

as compared to 1 . Compounds $40,49,51$, and 53 showed extraordinary results, compared with the current structure-activity relation (SAR) 1. Research has revealed that both hydroxyl groups at C-3 and C-6 are important for the activity and C-4 modifications can also increase the activity and anticancer properties of drugs. He et al. have reported that the microbial transformation of alpha mangostin (1) by Cunninghamella blakeslean resulted in two new glycosylation products, $\mathbf{5 6}$ and $\mathbf{5 7} .{ }^{57}$ Cytotoxicity $\mathbf{5 6}$ was comparable with alpha mangostin (1), whereas $\mathbf{5 7}$ had very low activity. The structure of alpha mangostin derivatives shown in Fig.-2.

A study on the development of the structural design of alpha mangostin by Narasimhan et $\mathrm{al}^{44}$ reported that xanthones (anthraquinone) core structure did not undergo structural modification while the iso-prenyl and phenolic hydroxy functional groups were semi-synthetic. Twelve modified compounds used in synthetic obtained by a semi-synthetic modification of alpha mangostin through the Ritter reaction, reduction with palladium-carbon (Pd-C), alkylation, and acetylation. After obtaining the synthetic compound from alpha mangostin modification, bioassay was carried out to obtain better activity than the main compound to become a potential drug candidate. The structural design mechanism is shown in Fig.-3.

33. $\mathrm{R}_{1}=\mathrm{H}, \mathrm{R}_{2}=\mathrm{COCH}_{3}$

34. $\mathrm{R}_{1}-\mathrm{R}_{2}=\mathrm{COCH}_{3}$

35. $\mathrm{R}_{1}=\mathrm{H}, \mathrm{R}_{2}=\mathrm{C}_{6} \mathrm{H}_{5} \mathrm{CO}, \mathrm{R}_{3}=\mathrm{H}$

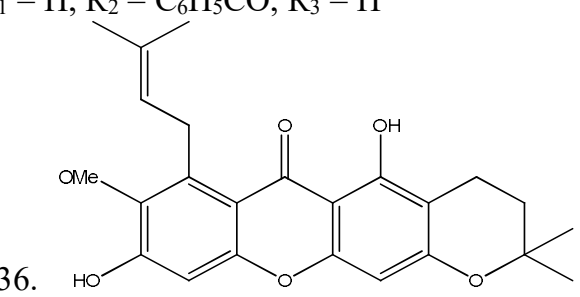

37.<smiles></smiles>

38. $\mathrm{R}_{1}=\mathrm{H}, \mathrm{R}_{2}=\mathrm{CH}_{2} \mathrm{COOH}, \mathrm{R}_{3}=\mathrm{H}$

39. $\mathrm{R}_{1}=\mathrm{R}_{2}=\mathrm{CH}_{2} \mathrm{COOH}, \mathrm{R}_{3}=\mathrm{H}$

40. $\mathrm{R}_{1}=\mathrm{H}, \mathrm{R}_{2}=\mathrm{CH}_{2} \mathrm{CH}=\mathrm{CH}_{2}, \mathrm{R}_{3}=\mathrm{H}$

50.<smiles>CC(C)(O)CCc1c(C(=O)O)c(O)cc2oc3cc4c(c(O)c3c(=O)c12)CCC(C)(C)O4</smiles>

41. $\mathrm{R}_{1}=\mathrm{R}_{2}=\mathrm{CH}_{2} \mathrm{CH}=\mathrm{CH}_{2}, \mathrm{R}_{3}=\mathrm{H}$

42. $\mathrm{R}_{1}=\mathrm{H}, \mathrm{R}_{2}=\mathrm{Tf}, \mathrm{R}_{3}=\mathrm{H}$

43. $\mathrm{R}_{1}=\mathrm{Tf}, \mathrm{R}_{2}=\mathrm{H}, \mathrm{R}_{3}=\mathrm{H}$

44. $\mathrm{R}_{1}=\mathrm{CH}_{3}, \mathrm{R} 2=\mathrm{CH}_{2} \mathrm{CH}, \mathrm{R}_{3}=\mathrm{H}$

45. $\mathrm{R}_{1}=\mathrm{R}_{2}=\mathrm{CH}_{2} \mathrm{CH}=\mathrm{CH}_{2}, \mathrm{R}_{3}=\mathrm{CH}_{3}$

46. $\mathrm{R}_{1}=\mathrm{H}, \mathrm{R}_{2}=\mathrm{H}, \mathrm{R}_{3}=\mathrm{CH}_{3}$<smiles>[R6]c1cc2oc3cc(Br)c(CCC(C)C)c(O)c3c(=O)c2c(CCC(C)C)c1C(C)=O</smiles>

47. $\mathrm{R}_{1}=\mathrm{H}, \mathrm{R}_{2}=\mathrm{OH}$

48. $\mathrm{R}_{1}=\mathrm{R}_{2}=\mathrm{H}$

49. $\mathrm{R}_{1}=\mathrm{H}, \mathrm{R}_{2}=\mathrm{NH}_{2}$

51.<smiles>CC(C)=CCc1c(O)c(Cl)c2oc3cc(O)c(C)c(CC=C(C)C)c3c(=O)c2c1O</smiles> 
RASĀYAN J. Chem.

Vol. 13 | No. 4 |2544-2551| October - December | 2020<smiles>Cc1c(O)c(CCC(C)C)c(O)c2c(=O)c3c(CCC(C)C)c([N+](=O)[O-])c(O)cc3oc12</smiles>

52. $\mathrm{R}=\mathrm{NH}_{2}$

53. $\mathrm{R}=\mathrm{NO}_{2}$<smiles>CC(C)=CCc1c(O)cc2oc3cc(O)c(Cl)c(CC=C(C)C)c3c(=O)c2c1O</smiles>

54. $\mathrm{R}=\mathrm{CH}_{2} \mathrm{CH}=\mathrm{CH}$

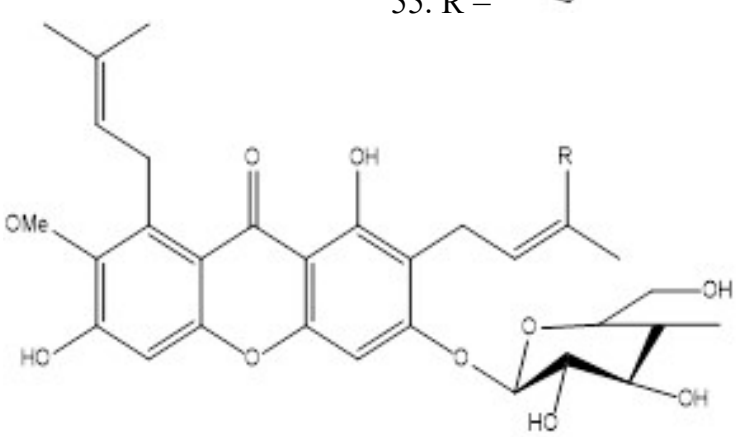

56. $\mathrm{R}=\mathrm{H}$

57. $\mathrm{R}=\mathrm{R}=\mathrm{CH}_{2} \mathrm{OH}$

Fig-2: Alpha Mangostin Derivatives
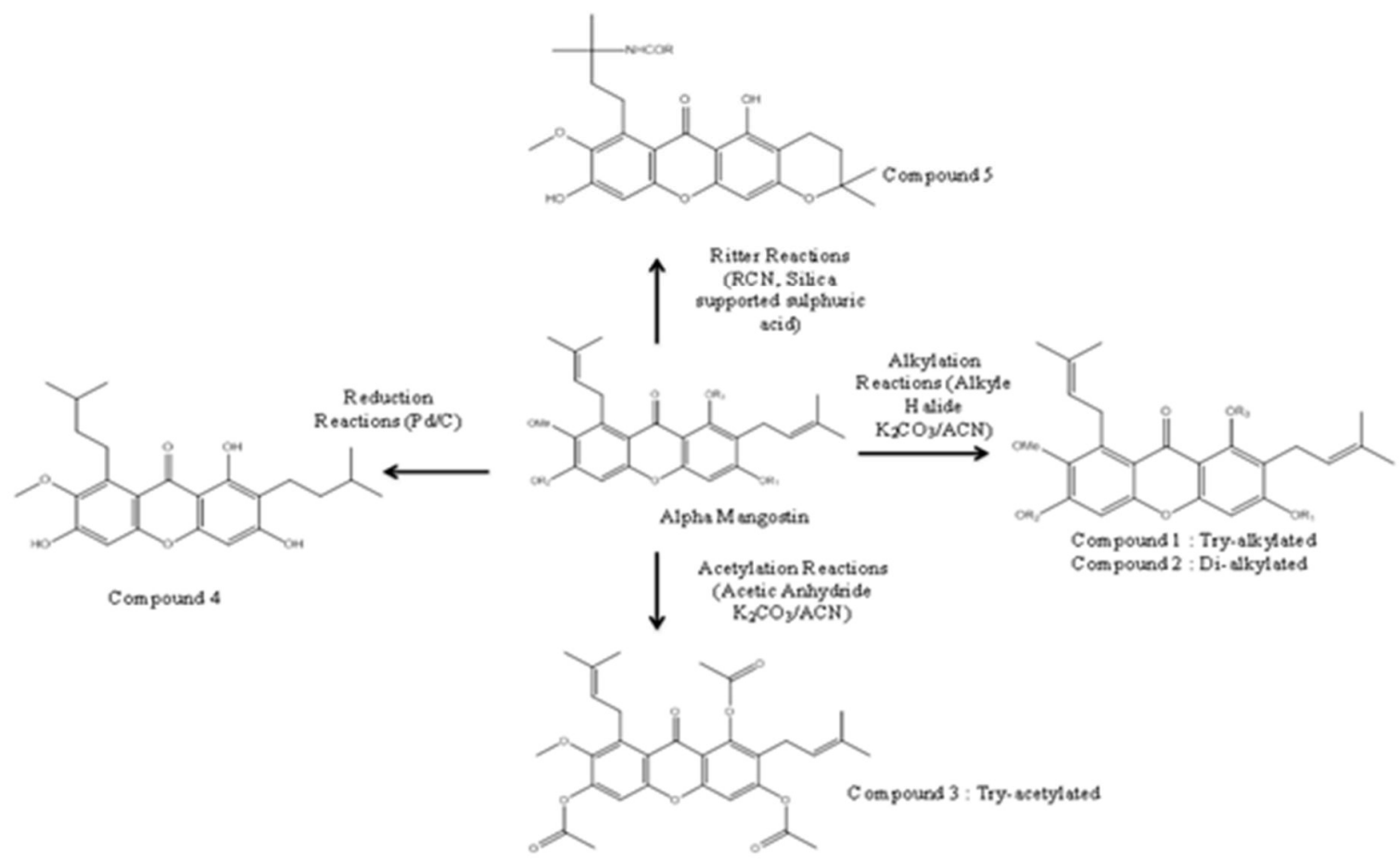

Fig.-3: Reaction Mechanism of Alpha Mangostin 
Increasing the anticancer activity of the breast and the physicochemical properties of the alpha mangostin compound can be done by designing the compound synthesis. Bioactivity considerations and pharmacological properties of alpha mangostin make this compound developed to treat various diseases. And from the various results obtained indicate that the alpha mangostin compound has strong effectiveness against breast cancer, this makes alpha mangostin and its derivatives can be candidates for new breast cancer drugs.

\section{ACKNOWLEDGMENT}

This study was supported by the master of pharmacy, Universitas Padjadjaran of Indonesia.

\section{REFERENCES}

1. S. R. Singh, Cancer Letters, 338(1), 1(2013), DOI:10.1016/j.canlet.2013.03.03

2. R. Siegel, D. Naishadham, CA: A Cancer Journal Clinicians, 62(5), 283(2012), DOI: $10.3322 /$ caac.20138/full

3. M. Muchtaridi, S. Megantara, D. Dermawan, M. Yusuf, Rasayan Journal of Chemistry, 12(4), 1927(2019), DOI: 10.31788/RJC.2019.1245391

4. P.Workman, B.Al-Lazikani, P.A.Clarke, Current Opinion in Pharmacology. 13(4), 486(2013), DOI: $10.1016 / j . c o p h .2013 .06 .004$

5. Jianling Wang, T. Laszlo Urban, DDW Drug Discovery World, 5(4), 73(2004).

6. P. S. Parmar and S. K. Patel, Rasayan Journal of Chemistry, 13(3), 1555(2020), DOI: 10.31788/RJC.2020.1335692

7. T. F. Stocker, D. Qin, G. K. Plattner, M. Tignor, S. K. Allen, J. Boschung and P. Midgley, Cambridge University Press, Cambridge, United Kingdom and New York, NY, US, p.1523(2013)

8. D. Obolskiy, I. Pischel, N. Siriwatanametanon and M. Heinrich, Phytotherapy Research: An International Journal Devoted to Pharmacological and Toxicological Evaluation of Natural Product Derivatives, 23(8), 1047(2009), DOI:10.1002/ptr.2730

9. J. Pedraza-Chaverri, N. Cárdenas-Rodríguez, M. Orozco-Ibarra and J. M. Pérez-Rojas, Food and Chemical Toxicology, 46(10), 3227(2008), DOI:10.1016/j.fct.2008.07.024

10. S. M. Widayanti, A. W. Permana and H. D. Kusumaningrum, Journal Pascapanen, 6(2), 6(2009), DOI: $124.81 .126 .59 /$ handle/123456789/7951

11. N. Tatiya-aphiradee, W. Chatuphonprasert and K. Jarukamjorn, Biomedicine and Pharmacotherapy, 111, 705(2019), DOI:10.1016/j.biopha.2018.12.142

12. J. Potisaen, N. Traiperm and P. Pariwat, Journal of Exercise Physiology Online, 22(7), 72(2019)

13. B. O. Cho, H. W. Ryu, Y. So, C. W. Lee, C. H. Jin, H. S. Yook, Y. W. Jeong, J. C. Park and I. Y. Jeong, Biomolecules and Therapeutics, 22(4), 288(2014), DOI:10.4062/biomolther.2014.052

14. D. L. Adiputro, H. Khotimah, M. A. Widodo, R. Romdoni, and D. Sargowo, Oxidants and Antioxidants in Medical Science, 2(1), 61(2013), DOI:10.5455/oams.170313.br.007

15. A. Rohman, M. Rafi, G. Alam, M. Muchtaridi and A. Windarsih, Journal of Applied Pharmaceutical Science, 9(8), 47(2019), DOI:10.7324/JAPS.2019.90807

16. A. Parkhe, P. Parekh, L. V. Nalla, N. Sharma, M. Sharma, A. Gadepalli and A. Khairnar, Neuroscience letters, 716, 134652(2020), DOI:10.1016/j.neulet.2019.134652

17. T. Andika, M. W. Wienanrno, K. Mulia, M. I. Arridjal, E. H. Purwaningsih and S. Farida, AIP Conference Proceedings, 2096, 030020(2019), DOI:10.1063/1.5096724

18. M. Y. Ibrahim, N. M. Hashim, A. A. Mariod, S. Mohan, M. A. Abdulla, S. I. Abdelwahab and I. Arbab, Arabian journal of Chemistry, 9(3), 329(2016), DOI:10.1016/j.arabjc.2014.02.011

19. H. S. Chae, S. R. Oh, H. K. Lee, S. H. Joo and Y. M. Chin, Food Chemistry, 134(1), 397(2012), DOI: 10.1016/j.foodchem.2012.02.075

20. J. J. Koh, S. Qiu, H. Zou, R. Lakshminarayanan, J. Li and X. Zhou, Biochimica et Biophysica Acta, 1828(1), 834(2013), DOI:10.1016/j.bbamem.2012.09.004

21. S. Al-Massarani, A. El-Gamal, N. Al-Musayeib, R. Mothana, O. Basudan, A. Al-Rehaily and L. Maes, Molecules, 18(9), 10600(2013), DOI:10.3390/molecules180910599 
22. Y. Sakagami, M. Iinuma, K. G. N. P. Piyasena, and H. R. W. Dharmaratne, Phytomedicine, 12(3), 203(2008), DOI:10.1016/j.phymed.2003.09.012

23. F. Rahmayanti, D. F. Suniarti, Z. A. Masud, Y. S. Wimardhani and G. P. Subita, Journal of International Dental and Medical Research, 10(1), 48(2017).

24. M. Sivaranjani, M. Prakash, S. Gowrishankar, J. Rathna, S. K. Pandian and A. V. Ravi, Applied Microbiology and Biotechnology, 101(8), 3349(2017), DOI:10.1007/s00253-017-8231-7

25. Kaomongkolgit, Ruchadaporn, K.Jamdee and N. Chaisomboon, Journal of Oral Science, 51(3), 401(2009), DOI: 10.2334/josnusd.51.401

26. N. M.Hashim, M. Y. Ibrahim, M. Yahayu, F. A. E. Omer, M. A. Rahman, N. Nordin, and G. E. C. Lian, PeerJ, 5, 3460(2017), DOI:10.7717/peerj.3460

27. M. Y. Ibrahim, N. M. Hashim, S. Mohan, M. A. Abdulla, S. I. Abdelwahab, I. A. Arbab and O. E. Ishag, Arabian Journal of Chemistry, 8(1), 129(2013), DOI:10.1016/j.arabjc.2013.11.017

28. H. N. Lee, H. Y. Jang, H. J. Kim, S. A. Shin, G. S. Choo, Y. S. Park and J. Y. Jung, International Journal of Molecular Medicine, 37, 939(2016), DOI:10.3892/ijmm.2016.2517

29. K. Jittiporn, P. Moongkarndi, J. Samer and W. Suvitayavat, Walailak Journal of Science and Technology, 15(8), 579(2018), DOI:10.48048/wjst.2018.3605

30. J. Markowicz, Ł. Uram, J. Sobich, L. Mangiardi, P. Maj and W. Rode, European journal of Pharmacology, 863, 172678(2019), DOI:10.1016/j.ejphar.2019.172678

31. W. Chaijaroenkul, Na-bangchang and Kesara, Acta Parasitologica, 60(1), 105(2014), DOI: 10.1515/ap-2015-0013

32. Y. Upegui, S. M. Robledo, J. F. Gil Romero, W. Quiñones, R. Archbold, F. Torres and F. Echeverri, Phytotherapy Research, 29(8), 1195(2015), DOI:10.1002/ptr.5362

33. S. Tjahjani, BMC Complementary and Alternative Medicine, 17(1), 1(2017), DOI:10.1186/s12906017-1649-8

34. M. Muchtaridi, Wijaya and C. Aprillianie, Asian Journal of Pharmaceutical and Clinical Research, 10(12), 440(2017), DOI:10.22159/ajpcr.2017.v10i12.20812

35. M. YIbrahim, N. M. Hashim, S. Mohan, M. A. Abdulla, S. I. Abdelwahab, B. Kamalidehghan and M. Yahayu, Drug Design, Development and Therapy, 8, 2193(2014), DOI: 10.2147\%2FDDDT.S66574

36. Li. Ping, W. Tian, and M. Xiaofeng, Molecular Cancer, 13(1), 1(2014), DOI:10.1186/1476-4598-13138

37. Akao, Yukihiro, Y. Nakagawa and Y. Nozawa, International Journal of Molecular Sciences, 9(3), 355(2008), DOI: 10.3390/ijms9030355

38. J. J. Chen, Z. J. Long, D. F. Xu, R. Z. Xiao, L. L. Liu, Z. F. Xu and Q. Liu, Leukemia and Lymphoma, 55(3), 628(2014), DOI:10.3109/10428194.2013.802312

39. T. Onodera, Y. Takenaka, S. Kozaki, T. Tanahashi, Y. Mizushina, International Journal of Oncology, 48(3), 1145(2016), DOI: 10.3892/ijo.2016.3321

40. T. S. Kim, T. T. Le, H. T. Nguyen, K. W. Cho and J. K. Sohng, Enzyme and Microbial Technology, 118, 76(2018), DOI:10.1016/j.enzmictec.2018.08.001

41. Manasathien, Jinnawat, Suranaree Journal of Science and Technology, 24(4), 475(2017)

42. Y. P. Tang, P. G. Li, M. Kondo, H. O. Ji, K. Kou and B. Ou, Journal of Medicinal Food, 12(4), 755(2009), DOI: 10.1089/jmf.2008.0204

43. Y. S. Won, J. H. Lee, S. J. Kwon, J. Y. Kim, K. H. Park, M. K. Lee and K. I. Seo, Food and Chemical Toxicology, 66, 158(2014), DOI:10.1016/j.fct.2014.01.040

44. S. Narasimhan, S. Maheshwaran, I. Abu-Yousef, A. Majdalawieh, J. Rethavathi, P. Das and P. Poltronieri, Molecules, 22(2), 275(2017), DOI:10.3390/molecules22020275

45. V. G. Guerrero, A. F. Baez, C. G. Cofré González and C. G. Miño González, Pan American Journal of Public Health, 41, 1(2017).

46. B. Hanstein, S. Djahansouzi, P. Dall, M. W. Beckmann and H. G. Bender, European Journal of Endocrinology, 150(3), 243(2004), DOI:10.1530/eje.0.1500243

47. A. Setiawati, Indonesian Journal of Pharmacy. 25(3), 119(2014), DOI: 10.14499/indonesianjpharm25iss3pp119 
RASĀYAN J. Chem.

Vol. 13 | No. 4 |2544-2551| October - December | 2020

48. J. Pedraza-Chaverri, N. Cárdenas-Rodríguez, M. Orozco-Ibarra and J. M. Pérez-Rojas, Food and Chemical Toxicology, 46(10), 3227(2008), DOI:10.1016/j.fct.2008.07.024

49. W. Pothitirat, M. T. Chomnawang, R.Supabphol and W.Gritsanapan, Fitoterapia, 80(7), 442(2009), DOI: $10.1016 / j$.fitote.2009.06.005

50. N. M. Saptarini and G. Hadisoebroto, Rasayan Journal of Chemistry, 13(2), 789(2020), DOI: $10.31788 /$ RJC.2020.1325533

51. Y. Wang, Z. Xia, J. R. Xu, Y. X. Wang, L. N. Hou, Y. Qiu and H. Z. Chen, Neuropharmacology, 62(2), 871(2012), DOI: 10.1016/j.neuropharm.2011.09.016

52. S. Kritsanawong, S. Innajak, M. Imoto and R. Watanapokasin, International Journal of Oncology, 48(5), 2155(2016), DOI:10.3892/ijo.2016.3399

53. Y. B. Lee, K. C. Ko, M. D. Shi, Y. C. Liao, T. A. Chiang, P. F. Wu and Y. W. Shih, Journal of Food Science, 75(1), 13(2010), DOI:10.1111/j.1750-3841.2009.01407.x

54. M. Muchtaridi, D. Dermawan, M. Yusuf, Journal of Young Pharmacists. 10(3), 252(2018) DOI: 10.5530 /jyp.2018.10.58

55. Y. Ren, S. Matthew, D. D. Lantvit, T. N. Ninh, H. Chai, J. R. Fuchs and A. D. Kinghorn, Journal of Natural Products, 74(5), 1117(2011), DOI:10.1021/np200051j

56. L. D. Ha, P. E. Hansen, O. Vang, F. Duus, H. D. Pham, L. H. D. Nguyen, Chemical and Pharmaceutical Bulletinl, 57(8), 830(2009),

57. X. Fei, M. Jo, B. Lee, S. B. Han, K. Lee, J. K. Jung and Y. S. Kwak, Bioorganic and Medical Chemistry Letters, 24(9), 2062(2014), DOI:10.1016/j.bmcl.2014.03.047

58. L. He, C. Zhu, Y. Yuan, Z. Xu and S. X. Qiu, Phytochemistry Letters, 9, 175(2014), DOI:10.1016/j.phytol.2014.06.009

[RJC-5769/2020] 